\title{
Beef heifers performance in natural grassland under continuous and rotational grazing in the autumn-winter
}

\author{
Desempenho de novilhas de corte em pastagem natural sob \\ pastoreio contínuo e rotativo no outono-inverno
}

\author{
Émerson Mendes Soares ${ }^{I^{*}}$ Fernando Luiz Ferreira de Quadros $^{\mathrm{I}}$ \\ Régis Maximiliano Roos de Carvalho ${ }^{I}$ Leandro Bittencourt de Oliveira ${ }^{\mathrm{I}}$ \\ Felipe Jochims ${ }^{I}$ Gabriela Machado Dutra ${ }^{I}$ Augusto Miranda Fernandes ${ }^{I}$ \\ José Pedro Pereira Trindade ${ }^{\mathrm{II}}$ Gustavo Freitas Ilha ${ }^{\mathrm{III}}$
}

\section{ABSTRACT}

The aim of this study was to evaluate the performance of beef heifers in natural grassland under continuous and rotational grazing during the autumn-winter period. The treatments were distributed in a completely randomized design and conducted using the forage mass above eight $\mathrm{cm}$ and $50 \%$ of the leaf blades mass of tussocks. The animals were Brangus beef heifers with initial body weight of $258 \mathrm{~kg}$. The variables evaluated were available forage mass (FMa), leaf blades mass of tussocks (LBMt), real forage allowance (FAr), sward height of the lower stratum (HLS), crude protein (CP), neutral detergent fiber (NDF), organic matter digestibility (OMD), total digestible nutrients $(T D N)$, average daily gain $(A D G)$, body condition score (BCS), reproductive tract score (RTS) and stocking rate (SR). FMa, HLS, $O M D$ and TDN decreased while FAr, CP and NDF were similar during the experimental period. The $A D G$ was positive only at third experimental period while BCS, RTS and SR decreased over time. The natural grassland management under continuous and rotational grazing during the autumn-winter period, using the forage mass above $8 \mathrm{~cm}$ and $50 \%$ of the leaf blades mass of tussocks, does not allow the adequate corporal development for breeding the beef heifers at 24 months old.

Key words: Pampa biome, reproductive tract score, grazing methods, heifers rearing, sward height.

RESUMO

O objetivo foi avaliar o desempenho de novilhas de corte em pastagem natural sob pastoreio contínuo e rotativo no outono-inverno. Os tratamentos foram distribuidos em um delineamento inteiramente casualizado, conduzidos utilizando a massa de forragem acima de oito cm e 50\% da massa de lâminas foliares das touceiras. Os animais foram novilhas Brangus com peso médio inicial de $258 \mathrm{~kg}$. As variáveis avaliadas foram massa de forragem disponibilizada (MFd), massa de lâminas foliares das touceiras (MLFt) oferta de forragem disponibilizada (OFd), altura do estrato inferior (Hinf), proteina bruta (PB), fibra em detergente neutro (FDN), digestibilidade da matéria orgânica (DISMO), nutrientes digestiveis totais (NDT), ganho médio diário (GMD), escore de condição corporal (CC), escore do trato reprodutivo (ETR) e taxa de lotação (TL). MFd, Hinf, DISMO e NDT foram decrescentes e OFd, PB e FDN semelhantes ao longo do periodo experimental. $O$ GMD foi positivo apenas no terceiro periodo, enquanto que CC, ETR e TL decresceram. O manejo da pastagem natural sob pastoreio contínuo ou rotativo, no outonoinverno, utilizando a massa de forragem acima de oito $\mathrm{cm} e$ $50 \%$ da massa de lâminas foliares das touceiras, não possibilita o desenvolvimento corporal adequado para acasalamento de novilhas de corte aos 24 meses.

Palavras-chave: bioma Pampa, escore do trato reprodutivo, métodos de pastoreio, recria de novilhas, altura da pastagem.

\section{INTRODUCTION}

The Pampa Biome natural grasslands has been the forage base to the livestock production in the Rio Grande do Sul state (RS, Southern Brazil) for more than three centuries. However, the research related to primary and secondary production in this ecosystem still are recent and reflected in the low reproductive indexes as a high maintenance of heifers to replacement ( $42 \%$ of the total herd of the state) (ANUALPEC, 2012). In this sense, the low reproductive efficiency in this category when they are reared in these grasslands

\footnotetext{
IDepartamento de Zootecnia, Universidade Federal de Santa Maria (UFSM), Avenida Roraima, 1.000, 97105-900, Santa Maria, RS, Brasil. E-mail: emersonsoares@gmail.com. "Corresponding author.

IIEmpresa Brasileira de Pesquisa Agropecuária (EMBRAPA Pecuária Sul), Bagé, RS, Brasil

IIIDepartamento de Clínica de Grandes Animais, UFSM, Santa Maria, RS, Brasil.
} 
is mainly credited to the absence of food planning and appropriate grazing strategies for breeding them early (CANELLAS et al., 2013).

The research results in these natural grasslands are distinct. There are some positive results in terms of primary and secondary production, as there are results demonstrating some restriction. However, some studies demonstrate the potential of these grasslands for rearing beef heifers (SOARES et al., 2005; MEZZALIRA et al., 2012) and, after that, breeding this category. Besides, to promote a higher livestock production efficiency is necessary to breed heifers until 24 months old due to her capacity of increasing the genetic progress of the herd, weight and number of calves for sale (BERETTA et al., 2001).

In pastoral environments, the pasture structure and its relation with the variables related to grazing process will determine the levels of primary and secondary production (GONÇALVES et al., 2009). The bite mass is the more important variable of the intake behavior once that it explains the higher percent of the range in the daily forage intake (MEZZALIRA et al., 2014). In this sense, some authors (UTSUMI et al., 2009; FONSECA et al., 2012) have related the bite mass with the sward height. GONÇALVES et al. (2009), in a natural grassland of the RS, determined the sward height of the lower stracta between eight and twelve $\mathrm{cm}$ as ideal for a maximum efficiency in the forage intake (i.e. higher bite mass) for beef heifers.

In addition, other possible ways to promote the efficiency of these grasslands could be the frequency control (i.e. grazing methods) and severity of defoliation (i.e. intensity) (CARVALHO, 2013). BRISKE et al. (2008) reviewed some trials with grazing methods and claim that there are not differences between them. However, among the trials compared, there are great differences in the grazing intensity settings and it makes hard (or makes unfeasible) the comparison between the methods (TEAGUE et al., 2013).

On that basis, the aim of this study was to evaluate the performance of beef heifers, for breeding at 24 months old, in a natural grassland under continuous and rotational grazing using the forage mass above eight $\mathrm{cm}$ and $50 \%$ of the leaf blades mass of tussocks, during the autumn-winter period.

\section{MATERIALS E METHODS}

The experiment was conducted in a natural grassland belonging to EMBRAPA CPPSSul, located at Bagé city (RS), in a transition zone between the Southern Campaign and Southeast hills. The climate is the $\mathrm{Cfb}$, temperate humid, according to Köpen classification with the historical average rainfall, between March and August, of 592mm and average temperatures of $16.2^{\circ} \mathrm{C}$ (INMET, 2013). During the experimental period the average temperature was $14.5^{\circ} \mathrm{C}$ and total rainfall was $477 \mathrm{~mm}$ (INMET, 2013). The evaluations were subdivided in six experimental periods (03/13 to $04 / 03 ; 04 / 04$ to $04 / 30 ; 05 / 01$ to $05 / 28 ; 05 / 29$ to $06 / 25 ; 06 / 26$ to $07 / 23 ; 07 / 24$ to $08 / 20$ ). Previous to the beginning of the experiment, experimental area was managed with beef cattle herd with low stocking rates $\left(<0.5 \mathrm{UA} \mathrm{ha}^{-1}\right)$ and, nine months before the beginning of the experiment, the area was mowed and remained excluded from grazing.

The treatments were two grazing methods: continuous (CONT) and rotational (ROT). In the CONT were used two areas with 4 .9ha each and in the ROT were used two areas with 5.6ha subdivided each one in eight paddocks of 0.7 ha. In the ROT treatment, the rotational criteria between the animals input and output was the time to thermal accumulative of 375 degree-day (DD). The DD was calculated through the sum of average daily temperatures. Thus, the number of days in each paddock was determined by average daily temperature necessary to reach a similar value to the division of 375 by number of paddocks less one. The rotation established was used to favor the native grass of the functional groups A and B (QUADROS et al., 2009). Furthermore, in the ROT it was selected a representative paddock (in each repetition) from the vegetation characteristics wherein were performed the evaluations of pasture.

During the experimental period, the area was managed with continuous and rotational grazing with a variable number of animals. For that, two criteria of pasture evaluations were used to define the forage mass available for the animals (FMa, $\mathrm{kg}$ DM $\left.\mathrm{ha}^{-1}\right)$ : forage mass above eight $\mathrm{cm}$ (FM8kg DM ha-1) in the lower stracta (sites with presence of prostrate species without presence of tussocks) (GONÇALVES et al., 2009) and $50 \%$ of the leaf blades mass of tussocks (LBMt, kg DM ha-1).

The forage mass (FM) was estimated through comparative yield method each day before the input of the animals in the representative paddock in the ROT treatment and, in the same day, it was estimated the FM in the area of the CONT. For the FM estimate, it was performed, previously, a survey about the tussock contribution (upper stracta) and lower stracta. Then, the number of evaluated points in each stracta was defined by its relative contribution in area. Thus, in each paddock, it was performed 20 visuals estimative of FM and six cuts, above ground, 
in a $0.25 \mathrm{~m}^{2}$ square. In the lower stracta, the cuts were performed stratified above and below of eight $\mathrm{cm}$ and, in the upper stracta without stratification. In each cut point it was performed three sward height measures using a sward stick. The sward height of lower stracta (HLS) was determined through the mean value obtained with the three measures.

For maintenance of grazing intensity criteria it was used a forage allowance (FA) of $12 \%$ from FMa (SOARES et al., 2005). Besides, starting from the fourth period $(25 / 06 / 2013)$ untill the end of the experiment, it was used a protein-energy supplement of auto-consumption to the heifers. It was used auto-consumption troughs and the supplement availability was verified weekly. On average, heifers intaked $0.05 \%$ of body weight (BW) per day of supplement, during the supplemented period.

The stocking rate (SR) was adjusted considering the following equation: $\mathrm{SR}=((\mathrm{FMa} / \mathrm{N})+$ FAR)/FA. Wherein, FMa is the forage mass available; $\mathrm{N}$ is the number of days in a paddock; FAR is the forage accumulation rate; FA is the forage allowance of $12 \%$. In the CONT, the $\mathrm{N}$ used was the period between two evaluations and, in the ROT, the $\mathrm{N}$ used was the average number of days of occupation in each paddock, during each period. The real forage allowance (FAr) was estimated using the following equation: $\mathrm{FAr}=(\mathrm{FMa} / \mathrm{N}+\mathrm{FAR}) / \mathrm{SR}$. In the ROT, the $\mathrm{FAr}$ was estimated using the instantaneous stocking rate data, during the occupation period of a paddock. The forage accumulation rate, (FAR, $\mathrm{kg} \mathrm{DM} \mathrm{ha-1}$ day $^{-1}$ ) was estimated with exclusion cages from grazing, according to triple pairing methodology (MORAES et al., 1990).

The pasture quality estimate was evaluated in each experimental period using the cuts of the available stracta (FM8 and LBMt) from FMa. The collected samples were analyzed to dry matter to $105^{\circ} \mathrm{C}$, crude protein (CP) (AOAC, 1997), organic matter in situ digestibility (OMD) (TILLEY \& TERRY, 1963), neutral detergent fiber (NDF) (SENGER et al., 2008) and total digestible nutrients (TDN) (estimated from OMD).

To testers-animals were used fifteen (15) Brangus heifers from EMBRAPA CPPSul herd with 17 months old and $258 \mathrm{~kg}$ BW on average in the beginning of the experiment. The animals were weighed in each experimental period with solid and liquid fasting of twelve hours and from this period were calculated the average daily gain (ADG, $\mathrm{kg} \mathrm{BW}$ animal $^{-1}$ day $^{-1}$ ). In the same evaluation, the animals were submitted to the body condition score (BCS) evaluation in a scale of 1 (very skinny) to 5 (very fat). At each experimental period evaluation was measured the hip height $(\mathrm{HH}, \mathrm{cm})$ with a graduated ruler (BIF, 2002) and weight:height ratio (W: $\mathrm{H}$, $\mathrm{kg} \mathrm{cm}^{-1}$ ) was calculated using the BW and $\mathrm{HH}$. To the reproductive tract score (RTS), it was used the methodology described by ANDERSON et al. (1991) using a scale between 1 (infant) and 5 (pubescent).

The experimental design was completely randomized with repetitive measures in the time with two treatments (continuous and rotational) and two areas of repetition. Data were submitted to variance analysis and $\mathrm{F}$ test with $5 \%$ of significance level. The regression analyzes were performed through Reg Procedure (Proc reg) and correlation analyses were performed through Corr Procedure (Proc corr). RTS and BCS were compared using the Chi-Square test. All analyses were performed with the statistical program $\mathrm{SAS}^{\circledR}$.

\section{RESULTS AND DISCUSSION}

There was no interaction between treatment $\times$ period for FMa, HLS and FAr $(\mathrm{P}>0.05)$ (Table 1). FMa, HLS and FAr were similar between grazing methods, continuous and rotational. There was difference in the FMa and HLS between the periods with decreasing values during the experimental period and with positive correlation between them $(\mathrm{r}=0.82 ; \quad \mathrm{P}<0.001)$. Meanwhile, $\mathrm{FAr}$ was similar between treatments and periods evaluated and it was a fundamental premise to allow the comparison between grazing methods. Besides, the bromatological pasture characteristics available to the animals were similar between treatments during the experimental period $(\mathrm{CP}=7.3 \% ; \mathrm{NDF}=78.2 \%) \quad(\mathrm{P}>0.05)$. There was only reduction in the OMD (34.2\%) and TDN (32.8\%) $(\mathrm{r}=0.65 ; \mathrm{P}<0.0001)$ along the experimental period. Anyway, $\mathrm{CP}$ never got below of the value (7\%) necessary to keep the growing of cellulolytic bacteria of the rumen (EGAN; DOYLE, 1985).

The FAR was null during the experimental period (data not shown) and in this way even with the adjust in the stocking rate, the forage harvested by the animals was reducing the mean value of FMa and HLS along the experimental period. SOARES et al. (2005) working in a natural grassland in the autumn-winter period, obtained similar value of FM in a similar FA. However, in this experiment the FAr value was greater than the pre-established $(12 \%)$ as well as PINTO et al. (2008) that obtained greater FAr values than the pre-established with herbage allowance protocols in a natural grassland.

There was no interaction between treatment $\times$ period for $\mathrm{ADG}, \mathrm{BCS}$ and RTS and these 
Table 1 - Available forage mass (FMa, kg DM ha ${ }^{-1}$ ), real forage allowance (FAr, kg DM $100 \mathrm{~kg}^{-1} \mathrm{BW}$ ), sward height of the lower stratum (HLS, cm), average daily gain (ADG, kg BW animal ${ }^{-1} \mathrm{ha}^{-1}$ day $^{-1}$ ), body condition score (BCS, 1 to 5), reproductive tract score (RTS, 1 to 5) and stocking rate (SR, $\mathrm{kg} \mathrm{BW} \mathrm{ha}^{-1}$ ) of beef heifers managed in a natural grassland under continuous and rotational grazing.

\begin{tabular}{|c|c|c|c|c|c|c|c|}
\hline Treatments & FMa & FAr & HLS & $\mathrm{ADG}$ & BCS & RTS & SR \\
\hline Rotational & 1423 & 17.4 & 9.1 & -0.3 & 2.47 & 1.44 & 617 \\
\hline Continuous & 1523 & 15.4 & 8.9 & -0.3 & 2.49 & 1.35 & 470 \\
\hline $\mathrm{STD}^{* *}$ & 375 & 1.4 & 0.9 & 0.03 & 0.03 & 0.08 & 150 \\
\hline $03 / 13-04 / 03$ & $2112^{\mathrm{ab}^{*}}$ & 14.3 & $12^{\mathrm{a}}$ & $-0.07^{b}$ & $3.11^{\mathrm{a}}$ & $1.76^{\mathrm{a}}$ & $866^{\mathrm{a}}$ \\
\hline $04 / 04-04 / 30$ & $2274^{a}$ & 19.1 & $12.4^{\mathrm{a}}$ & $-0.53^{\mathrm{de}}$ & $2.72^{\mathrm{b}}$ & $1.42^{\mathrm{b}}$ & $692^{\mathrm{ab}}$ \\
\hline $05 / 01-05 / 28$ & $1383^{\mathrm{bc}}$ & 11.9 & $10.8^{\mathrm{a}}$ & $0.11^{\mathrm{a}}$ & $2.62^{\mathrm{c}}$ & $1.57^{\mathrm{b}}$ & $676^{\mathrm{ab}}$ \\
\hline $05 / 29-06 / 25$ & $1222^{\mathrm{c}}$ & 15.1 & $7.5^{\mathrm{b}}$ & $-0.63^{\mathrm{e}}$ & $2.38^{d}$ & $1.23^{\mathrm{c}}$ & $468^{\mathrm{bc}}$ \\
\hline $06 / 26-07 / 23$ & $1081^{\mathrm{c}}$ & 18.4 & $5.1^{\mathrm{b}}$ & $-0.39^{c d}$ & $2.08^{\mathrm{e}}$ & $1.24^{\mathrm{c}}$ & $287^{\mathrm{c}}$ \\
\hline $07 / 24-08 / 20$ & $769^{c}$ & 19.4 & $6.1^{\mathrm{b}}$ & $-0.27^{\mathrm{c}}$ & $1.97^{\mathrm{f}}$ & $1.15^{\mathrm{c}}$ & $272^{\mathrm{c}}$ \\
\hline STD & 349 & 2.4 & 1.0 & 0.05 & 0.04 & 0.08 & 149 \\
\hline Treatment & 0.868 & 0.404 & 0.878 & 0.988 & 0.692 & 0.425 & 0.562 \\
\hline Period & 0.009 & 0.234 & $<0.001$ & $<0.001$ & $<0.001$ & $<0.001$ & $<0.001$ \\
\hline Int. Trat. $\times$ Per. & 0.798 & 0.202 & 0.984 & 0.329 & 0.388 & 0.412 & 0.991 \\
\hline
\end{tabular}

${ }^{*}$ Mean values followed by lowercase letters in the column differ by LSmeans test $(\mathrm{P}<0.05)$.

${ }^{* *}$ Standard deviation.

variable were similar between the treatments $(\mathrm{P}>0.05)$ (Table 1). ADG was positive only in the third period $(0.114 \mathrm{~kg})$ and, in the other periods it had negative value (between 0.072 and $0.633 \mathrm{~kg}$ ). Regardless the period differences, the animals showed a similar performance between treatments and it corroborates with BRISKE et al. (2008) which demonstrated that in $57 \%$ of the cases the grazing methods were similar in relation the animal variables. Furthermore, the BCS was decreasing along the experimental period wherein the animals lost 1.14 points in the BCS scale accompanied by a loss of $45 \mathrm{~kg}$ BW. The decrease in the BCS had a positive correlation with the reduction in the FMa ( $\mathrm{r}=0.63 ; \mathrm{P}=0,001)$, TDN and $\mathrm{OMD}(\mathrm{r}=0.8$; $\mathrm{P}<0.0001$ ) showing the animal response (individual performance) as much as the reduction in quantity of available food as the quality of the same.

GONÇALVES et al. (2009) worked with four sward heights (HLS 4, 8, 12 and $16 \mathrm{~cm}$ ), in a natural grassland with high density $\left(2070 \mathrm{~kg} \mathrm{DM} \mathrm{ha}^{-1}\right.$; HLS $8 \mathrm{~cm}$ ) determined sward heights between eight and twelve $\mathrm{cm}$ as the ideal to maximize the efficiency of forage intake (i.e. bite mass). MEZZALIRA et al. (2012) worked with FA protocols obtained value of $1398 \mathrm{~kg} \mathrm{DM} \mathrm{ha} \mathrm{k}^{-1}$ and $7.9 \mathrm{~cm}$ for FMa and HLS, respectively, in the $\mathrm{FA}$ of $12 \%$ with positive animal performance in the autumn-winter period. However, in this experiment, with FMa and HLS similar to the previous experiment, the animal performance was negative during the autumn-winter period, using the sward height of the lower stracta as one of the criteria to adjust the stocking rate. Nevertheless, the inclusion of the LBMt in the FMa may have been the main criteria to define the low animal performance.

The SR was similar between treatments and it was different along the experimental period (Table 1). Our results had SR greater than other experiments in natural grassland of RS with FA of 12\% (MEZZALIRA et al., 2012; PINTO et al., 2008). However, in our results, the FAr was based in the FM8 and LBMt (considering the percentage contribution of each stracta), differently to the experiments previously mentioned. Thus, the sampling realized can represent better the forage in the pasture, but the criteria of the inclusion of LBMt was arbitral, once that this research did not show if the quantity of this stracta effectively is intaked by the animals. There was no difference between treatments $(\mathrm{P}=0.48)$ in the inclusion of the LBMt (28\%) in the FMa. However, there was different between experimental periods $(\mathrm{P}<0.001)$, wherein there was a greatest LBMt contribution in the last experimental period $(56 \%)$ in relation to the previous $(22 \%)$. Then, it is evident that the great contribution of LBMt in the FMa could have overestimated the SR which, in turn, could have influenced negatively the animal performance, if the upper stracta species were not grazed effectively.

The SR had correlation with HLS $(\mathrm{r}=0.86$; $\mathrm{P}<0.0001)$ and FMa $(\mathrm{r}=0.8 ; \mathrm{P}<0.0001)$ as well FMa and HLS had a significant correlation $(\mathrm{r}=0.82$; 
$\mathrm{P}<0.001)$ and, besides, the regression model of SR adjusted to HLS $\left(\hat{Y}=-206.11+83.52\right.$ HLS; $r^{2}=0.73$; $\mathrm{P}<0.001)$. Meanwhile, the animal variables as ADG, RTS, BCS and $\mathrm{W}: \mathrm{H}$ did not have correlations with the forage variables, just correlations among themselves. Therefore, the SR increasing allowed by the inclusion of LBMt propitiated the occurrence of an overgrazing in the lower stracta (showed through the reduction in the HLS) as well, in the last period, a significative increase in the LBMt proportion in the FMa. The significant presence of conservative resources species (QUADROS et al., 2009), added with the historical of area utilization, propitiated the occurrence of an increase in the available heterogeneity, as evidenced by BAUMONT et al. (2005). On this way, these conditions may have hampered the grazing pattern of the animals, which is directly related to the dynamic of the lower and upper stracta (GORDON, 2000).

The RTS was decreasing along the experimental period with positive correlation with BCS $(\mathrm{r}=0.74 ; \mathrm{P}<0.0001)$, BW $(\mathrm{r}=0.78 ; \mathrm{P}<0.0001)$, $\operatorname{ADG}(\mathrm{r}=0.48 ; \mathrm{P}=0.002)$ and $\mathrm{W}: \mathrm{H}(\mathrm{r}=0.84 ; \mathrm{P}<0.0001)$. At the beginning of the experiment, $60 \%$ of the heifers had ovarian follicles $10-12 \mathrm{~mm}$ (indicating a start in the reproductive activity). However, from the third period, there were not heifers with ovarian follicles greater than eight $\mathrm{mm}$ and, furthermore, they stopped the developing of other reproductive structures. Still, through a linear regression, it was possible to adjust a model to RTS from BW $(\hat{\mathrm{Y}}=-1.502+0.012 \mathrm{BW}$; $\left.\mathrm{r}^{2}=0.62 ; \mathrm{P}<0.001\right)$ and $\mathrm{W}: \mathrm{H}(\hat{\mathrm{Y}}=-1.541+1.56 \mathrm{~W}: \mathrm{H}$; $\left.\mathrm{r}^{2}=0.7 ; \mathrm{P}<0.001\right)$. Using these equations, it was possible to evaluate that heifers would need a BW of $375 \mathrm{~kg}$ and a W:H of 2.9 for an adequate RTS for matting (RTS=3) (ANDERSON et al., 1991). Although the heifers had a $\mathrm{HH}$ adequate, the BW was not adequate to the reproductive tract development. Consequently, it was not adequate for breeding them at 24 months old.

\section{CONCLUSION}

The management of the natural grassland, both under continuous or rotational grazing during the autumn-winter, using the forage mass above eight $\mathrm{cm}$ and $50 \%$ of leaf blades mass of tussocks, it does not allow the beef heifers corporal development for breeding at 24 months old.

\section{ACKNOWLEDGEMENTS}

This experiment was funded by Coordenação de Aperfeiçoamento de Pessoal de Nível Superior(CAPES)EMBRAPA public notice (01-2011) and REPENSA project (562803/20106) funded by Conselho Nacional de Desenvolvimento Científico e Tecnológico (CNPq) FAPs public notice. The authors thank the Empresa Brasileira de Pesquisa Agropecuária (EMBRAPA CPPSul) for the availability of the experimental area and the fundamental aid in the experimental conduction.

\section{REFERENCES}

ANDERSON, K.J. et al. The use of reproductive tract scoring in beef heifers. Agri-practice, v.12, n.4, p.19-26, 1991.

ANUÁRIO DA PECUÁRIA BRASILEIRA (ANUALPEC). São Paulo: Instituto FNP, 2012. 380p.

ASSOCIATION OF OFFICIAL ANALYTICAL CHEMISTS (AOAC). Official methods of analysis. Gaithersburg, MD, 1997. 1298 .

BAUMONT, R. et al. How herbivores optimize diet quality and intake in heterogeneous pastures, and the consequences for vegetation dynamics. In: MILNE, J.A. (Ed.). Pastoral systems in marginal environments. Glasgow: J.A. Milne, 2005. p.39-50.

BEEF IMPROVEMENT FEDERATION (BIF). Guidelines for uniform beef improvement programs. Athens: Animal \& Dairy Science Department, The University of Georgia, 2002. 161p.

BERETTA, V. et al. Produtividade e eficiência biológica de sistemas pecuários de cria diferindo na idade das novilhas ao primeiro parto e na taxa de natalidade do rebanho no Rio Grande do Sul. Revista Brasileira de Zootecnia, v.30, n.4, p.1278-1286, 2001. Available from: $<$ http://www.scielo.br/scielo.php?pid=S1516-35982001000500022>. Accessed: May 29, 2014. doi:10.1590/S1516-35982001000500022.

BRISKE, D.D. et al. Rotational grazing on rangelands: Reconciliation of perception and experimental evidence. Rangeland Ecology and Management, v.61, n.1, p.3-17, 2008. Available from: $<$ http://county.wsu.edu/kittitas/Documents/Briske\%20Teague $\% 20$ Havstad\%202008\%20rotational\%20grazing\%20on\%20rangelands. pdf>. Accessed: May 29, 2014. doi:10.2111/06-159R.1.

CANELLAS, L.C. et al. Recria de fêmeas e idade ao primeiro acasalamento. In: MENEGASSI, S.R.O et. al. (Org.). Manejo de sistemas de cria em pecuária de corte. Guaíba: Agrolivros, 2013. Cap.5, p.85-97.

CARVALHO, P.C.F. Harry Stobbs Memorial Lecture: can grazing behavior support innovations in grassland management? Tropical Grasslands - Forrajes Tropicales, v.1, n.2, p.137-155, 2013. Available from: <http:/tropicalgrasslands.info/index.php/tgft/ article/view/81/44>. Accessed: May 29, 2014.

EGAN, J.K.; DOYLE, P.T. Effect of intraruminal infusion of urea on the response in voluntary feed intake by sheep. Australian Journal of Agricultural Research, v.36, n.3, p.483-495, 1985.

FONSECA, L. et al. Management targets for maximising the shortterm herbage intake rate of cattle grazing in Sorghum bicolor. Livestock Science, v.145, p.205-211, 2012. Available from: <http:// www.sciencedirect.com/science/article/pii/S1871141312000595\#>. Accessed: May 29, 2014. doi: 10.1016/j.livsci.2012.02.003.

GONÇALVES, E.N. et al. Relações planta-animal em ambiente pastoril heterogêneo: processo de ingestão de forragem. 
Revista Brasileira de Zootecnia, v.28, n.9, p.1655-1662, 2009. Available from: <http://www.scielo.br/scielo.php?script=sci_pd f\&pid=S1516-35982009000900003 > . Accessed: May 29, 2014 doi:10.1590/S1516-35982009000900003.

INSTITUTO NACIONAL DE METEROLOGIA (INMET). Estações automáticas - Gráficos. Available from: <http:// www.inmet.gov.br/portal/index.php?r=home/page\&page $=$ rede estacoes_auto_graf $>$. Accessed: Apr. 04, 2013.

GORDON, I.J. Plant-animal interactions in complex communities: from mechanism to modelling. In: HODGSON J. et al. (Eds.). Grassland ecophysiology and grazing ecology. Wallingford: CAB International, 2000. p.191-207.

MEZZALIRA, J.C. et al. Produção animal e vegetal em pastagem nativa manejada sob diferentes ofertas de forragem por bovinos. Ciência Rural, v.42, n.7, p.1264-1270,2012. Available from: $<$ http://www.scielo.br/scielo.php?script=sci_arttext\&pid $=$ S0103-84782012000700021 $>$. Accessed: May 29, 2014. doi: $10.1590 / \mathrm{S} 0103-84782012005000039$

MEZZALIRA, J.C. et al. Behavioural mechanisms of intake rate by heifers grazing swards of contrasting structures. Applied Animal Behaviour Science, v.153, p.1-9, 2014. Available from: <http://www.appliedanimalbehaviour.com/article/S01681591(13)00321-3/pdf>. Accessed: May 29, 2014. doi: 10.1016/j. applanim.2013.12.014.

MORAES, A. et al. Comparação de métodos de taxa de crescimento em uma pastagem submetida a diferentes pressões de pastejo. In: REUNIÃO ANUAL DA SOCIEDADE BRASILEIRA DE ZOOTECNIA, 27., 1990, Campinas, SP. Anais... Campinas: SBZ, 1990. p.332.

PINTO, C.E. et al. Produções primária e secundária de uma pastagem natural da Depressão Central do Rio Grande do Sul submetida a diversas ofertas de fitomassa aérea total. Revista Brasileira de Zootecnia, v.37, n.10, p.1-12, 2008. Available from: <http://www.scielo.br/scielo.php?script=sci_arttext\& pid $=$ S1516-35982008001000004 $>$. Accessed: May 29, 2014 . doi: 10.1590/S1516-35982008001000004.
QUADROS, F.L.F. de et al. A abordagem funcional da ecologia campestre como instrumento de pesquisa e apropriação do conhecimento pelos produtores rurais. In: PILLAR, V. de P. (Ed.). Campos sulinos: conservação e uso sustentável da biodiversidade. Brasília, DF: Ministério do Meio Ambiente, 2009. Cap.15, p.206-213

SEBRAE/SENAR/FARSUL. Diagnóstico de sistemas de produção de bovinocultura de corte do estado do Rio Grande do Sul. Porto Alegre: IEPE, 2005. 265p.

SENGER, C.C.D. et al. Evaluation of autoclave procedures for fibre analysis in forage and concentrate feedstuffs. Animal Feed Science and Technology, v.146, p.169-174, 2008. Available from: <http:// www.sciencedirect.com/science/article/pii/S0377840107005445>. Accessed: May 29, 2014. doi: 10.1016/j.anifeedsci.2007.12.008.

SOARES, A.B. et al. Produção animal e de forragem em pastagem nativa submetida a distintas ofertas de forragem. Ciência Rural, v.35, n.5, p.1148-1154, 2005. Available from: $<$ http://www.scielo.br/scielo.php?script=sci_arttext\&pid $=$ S0103-84782005000500025 $>$. Accessed: May 29, 2014. doi: $10.1590 / \mathrm{S} 0103-84782005000500025$.

TEAGUE R. et al. Multi-paddock grazing on rangelands: why the perceptual dichotomy between research results and rancher experience. Journal of Environmental Management, v.128, p.699-717. 2013. Disponível em: <http://www.sciencedirect. com/science/article/pii/S0301479713004131>. Accessed: May 29, 2014. doi: 10.1016/j.jenvman.2013.05.064

TILLEY, J.M.A.; TERRY, R.A. A two-stage technique of the "in vitro" digestion of forage crop. Journal British Grassland Society, v.18, n.2, p.104-111. 1963. Available from: <http:// onlinelibrary.wiley.com/doi/10.1111/j.1365-2494.1963.tb00335.x/ abstract>. Accessed: May 29, 2014. doi:10.1111/j.1365-2494.1963. tb00335.x.

UTSUMI, S.A. et al. Resource heterogeneity and foraging behaviour of cattle across spatial scales. BMC Ecology, v.9, p.9, 2009. Available from: <http://www.biomedcentral.com/14726785/9/9>. Accessed: May 29, 2014. doi: 10.1186/1472-6785-9-9. 